\title{
A NEUROLINGUISTIC ACCOUNT OF LEARNING BARRIERS IN THINKING PATTERNS: FROM THE PERSPECTIVE OF CLASSROOM WRITING IN ENGLISH
}

\author{
VIRGINIA M. PENG \\ Ritsumeikan University
}

ABSTRACT. Teaching English as a foreign language to students invariably encounters 3 learning barrierš: (1) the barrier between the instructor and students; (2) the barrier between the textbook author and the student; and (3) the barrier between the instructor and the textbook author. These are explained by applying neurolinguistic theory currently available in neuroscience.

To help students learn English, particularly regarding writing, the instructor faces challenges to overcome such barriers, because teaching any language to students of a different culture requires a great deal of adjustment of brain functions on all parties involved. This paper addresses one particular issue, adjustment of the thinking process, from a neurolinguistic point of view; it specifically presents classroom writings, by analyzing them, in order to propose a remedy.

The data are papers from first year university students. The materials were collected through participant observation and from student homework. These data are analyzed. The results of the analysis of the data are discussed in detail. The author concludes that pathways to students' protomeanings in the brain must be formed, and that repetition of exercises by relying on students' brain functions of memory can enhance understanding, because in writing, there is a large gap between writing a paragraph and an essay, which can be narrowed by the brain functions of memory.

\section{Initial remarks}

Teachers of English as a foreign language have always faced challenges by teaching the language which their students have little opportunities to use in class or elsewhere. Such challenges are always confronted by the problems of how to get across what the instructors have in mind to students learning the language. These problems are compounded by the difficulties, on the part of students, in understanding or comprehending the meanings of the authors of a textbook used in class which is written in English. These problems and difficulties constitute what may be called learning barriers which are manifold. Three may be singled out here: (1) The barrier between the instructor and his/her students, if the instructor uses English as the medium of instruction in class for 
explaining what s/he wants to get across; (2) the barrier between the author(s) of a textbook and the students using that textbook, especially when the textbook is written in English; (3) the barrier, to a lesser degree, between the instructor and the authors of the textbook being used in class. These barriers, however, are interrelated.

The first barrier, of course, is primarily based on what the instructor says in class which includes the instructor's understanding of the content of the textbook which is the meaning of what the author(s) had in mind when the textbook was written in the first place plus what the instructor wants to add or elaborate on his/her own. Thus, there are two parts in this barrier. From the point of view of students, however, the instructor wants to add or elaborate on his/her own. Thus there are two parts in this barrier. From the point of view of students, however, they are 2 in 1, because students take what is given orally by the instructor as one "integrated" whole, that is, a lecture.

The second barrier, in contrast, is visually oriented in that students read what is given in class or as assignment; they write down what is given orally or copy what is written on the blackboard by the instructor for mnemonic purposes; the assignment, however, is the designation of a part of the textbook and/or homework based on a portion of the textbook already covered, such as exercises.

The third barrier, on the other hand, is based on the combination of the oral instruction and the illustration(s) from the textbook pointed out by the instructor. The instructor moves back and forth between what $s /$ he thinks was the meaning the author(s) had in mind and what $\mathrm{s} / \mathrm{he}$ tries to explain and infer on the basis of his/her understanding of the textbook, i.e., the author(s)'s original meaning(s).

In Japan, teaching oral English has the same barriers, except that such barriers are further complicated by two relevant factors, not to mention the complex but different expectations the administrators and students have from the instructor: (1) For the majority of students, few opportunities are available to use the language. And (2) such discouraging situations add to the dwindling motivation of students. Both factors affect the instructor profoundly, thereby discouraging him/her from seriously contemplating the improvements of his/her instruction in order to help students overcome their learning barriers so as to improve their English.

In respect to the first factor, for one thing, classes are much too large for students to have sufficient time with a native English speaker, which in some cases may be the only opportunity. Many teachers have faced this same frustration in Japan and other countries. The problems are not new; even so, for another thing, the frustration stems from the fact that there is simply no desire on the part of the administration to solve them on account of financial stringency, be it in a university of a language school. 
In respect to the second factor, it is commonplace at least in Japan that students take English classes from junior high school, and then to some extent in college, not because they want to learn to speak that language but because English is compulsory in middle, secondary and higher education. Therefore, students just want to get passed each class or entrance examination to enter college by memorizing grammar assigned by teachers of English from textbooks written in Japanese; in many cases, teachers of English do not speak English in class, and they prefer to teach grammar of English in Japanese as their specialization.

A method of analysis regarding such barriers will be presented, which will propose a new direction to examine some of them within such stringency. This proposal will bring a linguistic and neurolinguistic perspective to those problems and difficulties faced by students as their learning barriers, thus presenting the new direction for an answer to teaching English as a foreign language in Japan and hopefully, elsewhere as well.

\section{Scope of Analysis}

The analysis will be based on the neurolinguistic theory as advocated by Peng in his review article of Thibault's Re-reading Saussure (2000). The theory emphasizes the need to take a hard look at what language really is, as was intended by Saussure in his book, entitled Cours de Linguistique Generale, which was published posthumously by his students. But it differs from Saussure's view in that it proposes that language has two aspects, like the two faces of Janus, one looking inward to the nervous system, which is the individual aspect consisting of two planes - content plane and expression plane - and the other looking outward to society, which is the social aspect. It is the individual aspect of language that will be the main concern in the present context.

By the individual aspect of language is meant that each individual's central nervous system and peripheral nervous system are involved in the production and reception of language as behavior in conjunction with the five senses, the brachial apparatus (for sign language) and the vocal apparatus (for oral language). And the patterning of social interactions in varying social contexts of situation, including classroom situation, among/between individuals within a community is what is meant by he social aspect of language.

In order to illustrate one portion of such vast problems and difficulties, the author has selected one realm of investigation from her experience in Japan; namely, the teaching of topic sentence in writing paragraphs and the teaching of thesis statement in writing an essay. Her intention for the selection is to share her experiences and ideas with other teachers of English so that they, too, can guide students to better organize their paragraphs and essays when writing paragraphs and essays in English. Such a guidance requires the change or ad- 
justment in students' thinking patterns; the adjustment, however, must be preceded by the removing of the learning barriers mentioned above.

The choice of this realm of investigation is based on the author's experiences that although to native speakers of English the concept of topic sentence may be relatively easier to grasp, it is much harder for speakers of other languages when learning to write English because of the learning barriers in thinking patterns.

The reason is that the notion of topic sentence is a "linguistic jargon" that covers a host of proto-meanings which cannot be accessed readily through the linguistic meanings by students whose primary language is not English. It is this kind of difficulty, which constitutes the said learning barriers, that will be demonstrated in this presentation in the hope that some kind of adjustment on the part of both the instructor and students can be worked out as remedy to improve the quality of thinking.

One way of overcoming such barriers is that if students have difficulty understanding the concepts of topic sentence and thesis statement, it may be a good idea for students to do exercises in Japanese first where they write out what they want to state in Japanese. The thesis statement can e pointed out in Japanese and then the organization can be suggested. Such an exercise would help students understand the concepts better.

As teachers, on the other hand, it is not possible to see inside each student's head; that is, it is impossible to know what the student is trying to say before they say it. Or, students must map meanings onto images (vocabulary), and produce such images as words in writing before the instructor can know whether or not students had the right meanings. If there are not images (i.e., not enough vocabulary items in the brain) in the first place, they cannot map meanings onto images for production.

Having students write in their native tongue first is deemed one way to overcome the learning barriers in thinking patterns, a prospect which will be further explained later. The reason is that students are facing not only difficulties in organization of thought but difficulties in expression as well; to take the inchoate mass of thinking (i.e., impulses roaming around in the brain) and organize it all in the head for writing is quite a task. Therefore, overcoming one barrier of expression by writing out words of what students want to say in Japanese could help putting inchoate four-dimensional mass of thinking onto twodimensional paper.

The selection of topic sentences as a realm of investigation may be further justified by the fact that the whole process of teaching a foreign language is so complex that the vast problems and difficulties cannot be demonstrated in their entirety; only such a selection can reveal the tip of the iceberg. One reason is that the instructor may have difficulty deciding or judging which sentence(s) is the topic sentence given the choice between a paragraph and an essay. For in- 
stance, a sentence may be chosen as a topic sentence in a paragraph, but are there going to be several topic sentences in the paragraphs form an essay, each having one topic sentence, or is there going to be just one topic sentence of the essay, serving as the thesis statement? More will be said about these questions later.

These questions may be compounded by the fact that the writing method in the textbook is really only one way for students to follow. As students become more creative, it becomes more difficult to have only one definition of topic sentence. When two or three people judge a piece of writing, they may judge a topic sentence differently. The reason is that each reader is reconstructing meanings form the writing in his/her own way. Therefore, reconstruction of meanings is each reader's brain may be different from the meanings that the writer had. There will be more complexities when judging the thesis statement from an essay, since many more meanings must be reconstructed to judge a thesis statement. Such being the case, topic sentence and thesis statement will be judged only by the author in the examples and data presented here, keeping in mind that others may find different topic sentences or thesis statements.

\section{Theoretical Constructs}

According to the neurolinguistic theory advocated by Peng (2000) language is memory-governed, meaning-centered, and multifaceted. Language is memorygoverned because language is behavior and all behaviors are memory-governed, language being one of the important behaviors for it id conducted in most activities.

Language is memory-governed not only in respect to first language but also in respect to second language acquisition which, too, is behavior. And it is this mental interaction of first language and second language acquisition which will be the main focus, for such mental interactions are precisely what the brain functions of language are the pertain to the individual aspect of language. Thus, students of different levels will have different kinds of memory with respect to English which they are trying to learn, just as there are also different memories regarding native language experiences; the brain functions of memory govern not only native tongue but also second language.

Language is meaning-centered because without meaning there is nothing to say. There are two kinds of meaning: proto-meaning and linguistic meaning. Between them there are different shades of meaning, each being realized upward as a nuance or an inference by the individual through the mechanism of function enhancement (Peng 1994).

By proto-meaning is meant each person's thought as an inchoate mass of impulses which is formulated through the five senses over time during the person's upbringing as an inchoate mass of thought, and may change throughout his/her lifetime because of the brain functions of memory which can fade, 
change, or improve. Such an inchoate mass of thought is made up of impulses which roam around in the brain waiting to be unlocked by corresponding sound images or graphic images, by way of catalytic mapping (for production) in order to form linguistic meanings, or by way of coupling (in the case of reception), through the process of identification to result in linguistic meanings.

When there are sufficient sound images of graphic images in the individual's brain functions of memory, s/he has already acquired a language because these images must be learned over time and constitute that person's vocabulary which is finite. There are no such things as an infinite set of sentences in each individual's brain; nor can s/he generate such a vast number of sentences in his/her lifetime because once that person dies, it is the end of his/her individual aspect of language, be it his/her first or second language.

There are two important points in Peng's theory; (1) in production, the individual constructs linguistic meanings out of proto-meanings (which constitute an inchoate mass of thought) through catalytic mapping, because $s /$ he has already had proto-meanings as his/her thought from childhood; (2) in reception, the individual must reconstruct on the basis of in-coming stimuli (i.e., new experiences) both linguistic meanings and proto-meanings (which become new ideas or concepts as part of his/her thought) through first identification and then coupling.

When an individual can no longer construct linguistic meanings from protomeaning in production or reconstruct linguistic meanings and proto-meaning in reception, that individual is either dead or comatose. That is why the meanings an individual constructs may or may not be the same as the meanings another individual reconstructs, even though the sounds uttered or words written by the first individual and the sounds heard or words read by the second individual are the same.

What is then linguistic meaning? From the point of view of speaker, linguistic meanings are meant the result of certain portions of the inchoate mass of impulses (which is thought) that are catalytically mapped onto their corresponding sound images or graphic images for production as sounds or written symbols, respectively. These portions of proto-meanings in the brain become quite specific, as a direct result of catalytic mapping, but unstable on the ground that they are subject to modification by the on-going social contexts of situation which affect the individual's five senses.

The mapping is catalytic because when it is accomplished in the brain the linguistic meanings and their corresponding sound images or graphic images will have to be separated again in order to allow the sound images or graphic images which are also impulses to come out as sounds or written words through the vocal apparatus or brachial apparatus, respectively.

The catalytic mapping is therefore a process that is accomplished in the brain. Then and only then does the individual have linguistic meanings as part 
of the construction of meaning, because each acoustic image or graphic image corresponds to a definite meaning (concept) in the individual's thought; that definite meaning is linguistic meaning. Of course, without the presence of proper first language sound images in an individual's brain, that individual is either severely demented at best or jargonaphasic at worst; without proper first language graphic images in the brain, that individual is illiterate.

When the catalytic mapping is accomplished, in the individual's brain, it is a stage of brain functions called language potentiation because the impulses of linguistic meanings and their corresponding sound images or graphic images are to be separated again.

What follows language potentiation is that in both oral production or writing, linguistic meanings do not come out through the vocal apparatus or brachial apparatus at all; only sound images or graphic images come out as vocal sounds or written symbols, through the extrapyramidal tract in the brain, because of the process of separation mentioned above; the linguistic meanings along with the original proto-meanings are then left behind in the individual speaker's/writer's brain. In other words, speaker or writer constructs his/her own linguistic meanings through catalytic mappings but leave them behind in the process of separation for production.

From the point of view of hearer or reader, linguistic meanings are what s/he must reconstruct by way of coupling the sounds heard or the words read through identification to their corresponding meanings; they results are first linguistic meanings and then proto-meanings or the true meanings in a process called function enhancement to get the nuances or inferences or amusement as in puns and jokes. This is because sounds or written symbols have no meaning in and by themselves. Only when they are identified and then coupled in hearer's or reader's brain to their corresponding meanings for the reconstruction of such meanings does the individual as hearer or reader have the understanding of what $s /$ he hears or reads.

But this process of coupling has a prerequisite; that is, the individual has already acquired a host of sound images and/or graphic images (i.e., the needed vocabulary) in the brain ready to be identified with the in-coming impulses of sounds or written symbols before the process of coupling; without these sound images and/or graphic images, the sounds heard or written symbols seen are sheer noises or simply smears. After the brain functions of identification, the sounds or written symbols so identified undergo the process of coupling of them to their corresponding linguistic meanings for the initial understanding of what those in-coming words are. Then and only then will the individual (hearer or reader) be able to comprehend the message as a result of the coupling, a message that may or may not be the true meaning (or proto-meaning) will dawn on hearer or reader only after s/he undergoes function enhancement in his/her brain by combining other information.

In sum, speaker or writer leaves his/her meanings $s /$ he has constructed behind in the brain and hearer or reader reconstructs his/her meanings which may 
or may not be the same as the meanings left behind by the speaker or writer; nine times out of ten, the constructed meanings and the reconstructed meanings are not the same, hence the vast challenging problems facing the instructor.

The teaching of a second language, such as English, to speakers of other languages lies in how to allow the learners to form sound images or graphic images in their brains from the manipulation of catalytic mappings and of identification and coupling. Once they have formed enough such images, they will then be able to undergo two processes in their brain functions:

(1) They can catalytically map certain portions of their inchoate mass of impulses (proto-meanings which they already have as thought) onto their newly stored sound images or graphic images of the second language, e.g. English, in order to formulate the corresponding linguistic meanings which the students must garner in their brains to reach the stage of language potentiation.

(2) And they can identify in-coming impulses of sounds or written symbols with the corresponding sound images or graphic images already stored in their brains, so as to couple these images to their corresponding linguistic meanings and ultimately, when they become more proficient, to the proto-meaning for the true meaning through function enhancement (as in the case of puns and jokes).

In the present context, these two processes of constructing and reconstructing meanings are pivotal, which is why language is meaning centered; they are vital to second language learning on the basis of which second language teaching may be accomplished.

Language is also multifaceted because it includes not only oral language but also sign language and written language and can be expressed through Braille as well. There are of course different results in terms of speaking and writing and signing, because the pathways from the cerebrum to the outputs (oral apparatus and brachial apparatus) are different. At one and the same time, acoustic images for oral language and graphic images for written language are stored in the brain functions of memory at different points in time for each individual's first language. In other words, even a native speaker learns to speak before $s / h e$ learns to write. Such is also the case in second language learning, even though some teachers may start out with teaching the alphabet and vocabulary items for memorization before the students learns to speak a foreign language.

\section{Source of Data}

The data which will be presented in this paper come from one institution which is a four-year university. The subjects are selected from one level of first year students, although students at this institution are required to go through two years of English before they can graduate from this four-year university. Prior to entrance, however, all students must have completed high school education, 
where English is taught, either in Japan or overseas; some of them are transfers from other universities of other faculties of this institution to become sophomores; hence, a placement test is deemed necessary in each year for in-coming freshman and second year students.

As a result, in-coming freshmen can then be placed in different levels of first year classes. The levels of first year students are based on the placement test given at the beginning of the year. The placement test is one which resembles the TOEFL test. For the second year students, their placement depends on the TOEFL-ITP scores which were also taken prior to admission.

Freshmen are assigned to five levels of classes as first year students: basic, intermediate, upper-intermediate, advanced, super advanced. Second year students are assigned to four levels: basic, intermediate, upper-intermediate and advanced. Only first year students from one level, namely, advanced level, were chosen as subjects whose data will be used for analysis.

\section{Purpose}

The purpose of this presentation is three-fold; (1) to present a case study of classroom writings form Japan in regard to the learning barriers in thinking patterns students of English in Japan face; (2) to analyze the problems and difficulties form the point of view of neurolinguistics advocated by Peng, so as to suggest a remedy for teaching English in general; and (3) to propose a better teaching method on the basis of such a remedy.

(1) The case study to be presented here is confined to Japanese students of English. But the implication is that teachers of other students in different countries, even though the nature of such problems in each country also differs because of the students' cultural backgrounds and their mother tongues, may also be able to make use of the findings from this case study for their own benefits. The theoretical underpinnings of this implication is that classroom writing is a common problem not only with students of English in Japan but also with students of English elsewhere.

(2) Classroom writing in English is often approached from a linguistic point of view, such as paragraph writing or theme writing. The method of approach to such materials is based on the assumption that each student, having learned to speak some English, is capable of putting that kind of English into writing.

The assumption presupposes that the student has little problems with his/her own thinking patterns when writing, that is, when constructing linguistic meanings of English from his /her native thinking patterns. Form the neurolingusitic point of view, however, this assumption is contrary to hard facts, because there are many problems in the catalytic mappings of his/her thought as native thinking onto the newly formulated but small number of sound images and graphic 
images of English to construct corresponding linguistic meanings. It is in this regard that a neurolinguistic remedy will be proposed, which is ontological in nature.

(3) The ontological nature of this neurolinguistic point of view is that thought is formulated through memory which is experience-based and timesensitive. Without memory, there is no though of any kind and hence nothing to talk about or write about. Thought changes overtime because of different experiences encountered by each individual throughout his/her lifetime. Hence, memory is experience-based.

Memory is also time-sensitive because it is subject to forgetting. Those few privileged people who have photographic memory may be bombarded by past experiences which they cannot forget. Moreover, because the pathways from the cerebrum leading to the oral apparatus transduce impulses linearly, on account of one tongue for each person. Nobody can utter two sounds, let alone two words, simultaneously. Each sound is an impulse or a series of impulses and, therefore, the impulse that comes out first must be erased from the pathways to allow the impulse that come next to go through the same pathways. Or else the individual will have the clinical symptom of perseveration, which is pathological.

In the case of sign language, since there are two upper limbs sometimes two signs can be expressed simultaneously, for example, brother and sister in Japanese sign language (JSL). But using simultaneity in oral language is impossible while it is feasible to some extent in sign language; in the same vein, no one can write two words with one hand simultaneously, although using two hands to write for ambidextrous people might be possible.

Because of these anatomical constraints in respect to brain functions, the remedy to be proposed later is necessarily neurolinguistic in nature. It is on the basis of such a remedy that the author will propose a better teaching method.

\section{Method and materials}

The method employed for this study was embroidered in classroom interactions based on (1) participant observation and (2) the conduction of students' homework assigned by the author. The participant observation was the teaching itself by the author in class aiming at her students' proper comprehension of the textbook illustrations, such as topic sentences and the arrangement of paragraphs for an appropriate thesis statement; the students were supposed to weigh the differences between different kinds arrangements in the paragraphs presented. This participant observation tended to be rather vague because the instructor could only guess that the students understood the explanation regarding the assessment of the paragraphs illustrated; without the reactions or reproduction 
on the part of each student in writing or in some form of expression, the instructor had no way of knowing whether the students understood (i.e., reconstructed) the correct meanings of what the instructor said in the explanation and illustration. Note that if hearer does not respond in some form of expression, there is no way in which speaker can know what went on in hearer's brain.

The assignment for homework was the second part of the method employed whereby the students could then express what they thought they had understood from the instructor's explanation. In other words, the homework was to allow the students to apply what the instructor had in mind to their own work which would then give the instructor some ideas of whether the students had understood what had been presented in the classroom.

The materials collected were homework returned by the students to the instructor. They were asked to write two separate paragraphs and one essay and one revision of the first paragraph. Since four written assignments were given to each student as homework and there were 27 students in the class, there are 108 written assignments for analysis. The sequence of the assignments was as follows:

Paragraph 1 was assigned to students first. It was returned to the instructor later. Some discussion of students' paragraphs and topic sentences was then done in class; they were to rewrite paragraph 1 and turn it in again. Later, the students were assigned essay 1 . After correction, essay 1 was returned to them with more assignments on essay writing and thesis statements. Paragraph 2 was assigned after essay 1 .

\section{Subjects}

The subjects of this study were first year students in economics. These students had already completed one semester of English. Thus, they have had to hand in reports or essays written in English of various lengths, but had never had formal training in writing. The subjects were at the advanced level and were to focus on academic English. There were 30 students registered in the class but only 27 of them handed in their homework.

\section{Results of analysis}

The results come from the analysis of the homework turned in by the students consisting of 2 paragraphs, 1 revision and 1 essay per student. The 2 paragraphs vary in lengths depending on each student's capacity. Most students produced the two paragraphs in more or less the same length. Some, however, had one paragraphs longer than the other. Paragraph 1 was rewritten by the length was generally the same as the original version. 
The instructor went through the homework and used her own judgment by following the definitions of "topic sentence" and "thesis statement" as outlined in the textbook. She then set up three criteria for the analysis of the materials.

\section{Definition from the Textbook}

The definition of topic sentence is from Ready to Write More by Blanchard and Root (1997); they provide a definition of topic sentence as having the topic of the paragraph, providing a controlling idea and providing the writer's attitude about the topic. Similarly, thesis statement, which is the topic sentence for an essay, is defined as identifying the subject and giving aspects about the subject to be discussed. The textbook also provides good examples for students and leads them from paragraph writing to essay. writing.

Although the examples are good, when students write by themselves, it becomes more challenging to produce a topic sentence from their limited graphic images (i.e., vocabulary) on account of the learning barriers mentioned further above. In the case of essay writing, likewise, the authors give a fiveparagraph essay as an example in the textbook. For students who understand English readily, the recognition of the thesis statement in and reorganization of the five-paragraph essay might be simpler. But when students do not understand English concepts, because of the learning barriers which are now in the way, there can be a problem to recognize the thesis statement in and reorganize the paragraphs for the exemplar essay, not to mention the problem in the assignment of an essay which they are supposed to write in English; they may have difficulties in understanding why the authors of the textbook chose that particular thesis statement in the example over the others thereof as the best solution for the organization of paragraphs in the essay.

\section{Criteria for Analysis}

In order to analyze the data, the author set up three criteria for each paragraph (and the revision) and three criteria for the essay. That is, using her own judgment, she marked "correct", "incorrect" or "vague" topic sentences for the paragraphs and the revision; likewise, she also marked "correct", "incorrect" or "vague" thesis statements for the essay. No attempt was made to change or correct the students' grammatical errors. The errors are left intact. For the paragraphs, "correct" is meant that the meaning of the sentence is in line with the textbook; that is, the topic and controlling idea and attitude are written as the first sentence. By "incorrect" is meant that the student has no idea of the definition of topic sentence; the sentence is too general or narrow, or that no other 
sentence in the paragraph would be close to a topic sentence. By "vaguely correct" is meant that the student's topic sentence fits the definition of topic sentence from the textbook, but it is not the first sentence of the paragraph.

For the essay, similar criteria are used. For "correct", the thesis statement must be similar to what is stated in the book; that is, the thesis statement gives the subject and aspects of the subject to be discussed. By "incorrect" is meant that the student does not have a sentence which reflects the subject or aspects of the subject in one sentence. In some essays, "vaguely correct" is simply that the author was not sure what the students wanted to say. Reconstructing the thesis statement from what those students wrote in their essays is difficult. The results of the analysis can be found in Tables 1 to 4 .

Table 1: Topic Sentences From Paragraph 1

\begin{tabular}{|c|c|c|c|}
\hline Subjects & Correct & Incorrect & Vague \\
\hline 1 & $\begin{array}{l}\text { I like traveling very much, } \\
\text { so I become a tour conduc- } \\
\text { tor. }\end{array}$ & & \\
\hline 2 & & I major in Economic. & \\
\hline 3 & $\begin{array}{l}\text { If I have a time to go for a } \\
\text { trip this weekend, I'd like } \\
\text { to go to Kyoto. }\end{array}$ & & \\
\hline 4 & & $\begin{array}{l}\text { Even if it listens with "What } \\
\text { kind of occupation do you } \\
\text { want to get in the future? Or, } \\
\text { what do I want to do?" I can } \\
\text { answer that soon. }\end{array}$ & \\
\hline 5 & & Color actually affects us. & \\
\hline 6 & & $\begin{array}{l}\text { When I was high school } \\
\text { student, my friend said to } \\
\text { me that he wanted to } \\
\text { become a guide. }\end{array}$ & \\
\hline 7 & & $\begin{array}{l}\text { Color giver us various } \\
\text { meanings. }\end{array}$ & \\
\hline 8 & $\begin{array}{l}\text { I chose economics because } \\
\text { this have "Service Man- } \\
\text { agement Institute". }\end{array}$ & & \\
\hline 9 & $\begin{array}{l}\text { There are many kinds of } \\
\text { job that requires lots of } \\
\text { travel. }\end{array}$ & fer & \\
\hline \multicolumn{4}{|l|}{10} \\
\hline 11 & & $\begin{array}{l}\text { To go abroad to work is } \\
\text { many people are required } \\
\text { in the future }\end{array}$ & \\
\hline 12 & & $\begin{array}{l}\text { I, now, belong to the Fi- } \\
\text { nance Institute, Econom- } \\
\text { ics. }\end{array}$ & \\
\hline
\end{tabular}




\begin{tabular}{|c|c|c|c|}
\hline Subjects & Correct & Incorrect & Vague \\
\hline 13 & $\begin{array}{l}\text { The reasons that I selected } \\
\text { human economy course is } \\
\text { to think how will be people } \\
\text { and environment of the } \\
\text { world in the future. }\end{array}$ & & \\
\hline 14 & & $\begin{array}{l}\text { I wouldn't like to be a } \\
\text { movie star. }\end{array}$ & \\
\hline 15 & & $\begin{array}{l}\text { Movie star act many char- } \\
\text { acters. }\end{array}$ & \\
\hline \multicolumn{4}{|l|}{16} \\
\hline 17 & & I want to live in 1700 s. & \\
\hline 18 & & $\begin{array}{l}\text { Many kinds of color affect } \\
\text { me two influences. }\end{array}$ & \\
\hline \multicolumn{4}{|l|}{19} \\
\hline 20 & & $\begin{array}{l}\text { Movie gives us an impos- } \\
\text { sible dream. }\end{array}$ & \\
\hline 21 & $\begin{array}{l}\text { If I could live in any period } \\
\text { of time, I would like to live } \\
\text { in the end of Edo era. }\end{array}$ & & \\
\hline 22 & $\begin{array}{l}\text { I would like to be a movie } \\
\text { star for several reasons. }\end{array}$ & & \\
\hline 23 & & $\begin{array}{l}\text { There are lucky color and } \\
\text { unlucky color for me. }\end{array}$ & \\
\hline \multicolumn{4}{|l|}{24} \\
\hline 25 & $\begin{array}{l}\text { I would like to be a movie } \\
\text { star and I have three rea- } \\
\text { sons about it. }\end{array}$ & & \\
\hline 26 & & $\begin{array}{l}\text { Red, blue, black, ... we } \\
\text { always see so many colors } \\
\text { in daily life. }\end{array}$ & \\
\hline 27 & $\begin{array}{l}\text { There are some benefits } \\
\text { and good advantages for } \\
\text { the people who in the job } \\
\text { that requires a lot of travel } \\
\text { I think. }\end{array}$ & & \\
\hline Total & 9 & 14 & \\
\hline
\end{tabular}

Table 2: Topic Sentences From the Revised Paragraph 1

\begin{tabular}{|c|l|l|l|}
\hline Subjects & \multicolumn{1}{|c|}{ Correct } & \multicolumn{1}{c|}{ Incorrect } & Vague \\
\hline 1 & $\begin{array}{l}\text { I like traveling very much, } \\
\text { so I became a tour conduc- } \\
\text { tor. }\end{array}$ & & \\
\hline 2 & & I major in economic. & \\
\hline 3 & $\begin{array}{l}\text { If I have a time to go for } \\
\text { trip this weekend, I'd like } \\
\text { to go to Kyoto. }\end{array}$ & & \\
\hline
\end{tabular}




\begin{tabular}{|c|c|c|c|}
\hline Subjects & Correct & Incorrect & Vague \\
\hline 4 & & $\begin{array}{l}\text { Even if it listens with } \\
\text { "What kind of occupation } \\
\text { do you want to get in the } \\
\text { future? Or. What do I want } \\
\text { to do?" I can answer that } \\
\text { soon. }\end{array}$ & \\
\hline 5 & & Color actually affects us. & \\
\hline 6 & & $\begin{array}{l}\text { One of my friends wants to } \\
\text { become a guide for travel- } \\
\text { ing. }\end{array}$ & \\
\hline 7 & & $\begin{array}{l}\text { Color giver us various } \\
\text { meanings. }\end{array}$ & \\
\hline 8 & $\begin{array}{l}\text { I chose Economics be- } \\
\text { cause this has "Service } \\
\text { Management Institute". }\end{array}$ & & \\
\hline 9 & $\begin{array}{l}\text { There are many kinds of } \\
\text { jobs that require lots of } \\
\text { travel. }\end{array}$ & & \\
\hline \multicolumn{4}{|c|}{$x_{1-2}$} \\
\hline 11 & & $\begin{array}{l}\text { I want to go where people } \\
\text { speak English by not a } \\
\text { travel but work. }\end{array}$ & \\
\hline 12 & $\begin{array}{l}\text { I chose the Finance Insti- } \\
\text { tute in the faculty of Eco- } \\
\text { nomics for several reasons. }\end{array}$ & & \\
\hline 13 & $\begin{array}{l}\text { The reasons that I selected } \\
\text { human economy course is } \\
\text { to think how will be peo- } \\
\text { ple and environment of the } \\
\text { world in the future. }\end{array}$ & & \\
\hline 14 & $\begin{array}{l}\text { I would not like to be a } \\
\text { movie star for some rea- } \\
\text { sons. }\end{array}$ & & \\
\hline 15 & & $\begin{array}{l}\text { I long for a movie star } \\
\text { from childhood, but when } \\
\text { it comes to the crunch, I } \\
\text { wouldn't like to be a } \\
\text { movie star. }\end{array}$ & \\
\hline \multicolumn{4}{|l|}{16} \\
\hline 17 & & $\begin{array}{l}\text { My favorite country is the } \\
\text { U.S. and I like some presi- } \\
\text { dents because I learned it } \\
\text { in high school. }\end{array}$ & \\
\hline 18 & $\begin{array}{l}\text { Many kinds of color affect } \\
\text { us in two ways. }\end{array}$ & & \\
\hline \multicolumn{4}{|c|}{ (2) } \\
\hline 20 & & $\begin{array}{l}\text { I think a movie star is a } \\
\text { brilliant job. }\end{array}$ & \\
\hline
\end{tabular}




\begin{tabular}{|c|l|l|l|}
\hline Subjects & \multicolumn{1}{|c|}{ Correct } & Incorrect & Vague \\
\hline 21 & $\begin{array}{l}\text { If I could live in any pe- } \\
\text { riod of time, I would like } \\
\text { to live in the end of Edo } \\
\text { era. }\end{array}$ & & \\
\hline 22 & $\begin{array}{l}\text { I would like to be a movie } \\
\text { star for several reasons. }\end{array}$ & & \\
\hline 23 & $\begin{array}{l}\text { My feeling is often af- } \\
\text { fected by color. }\end{array}$ & & \\
\hline 24 & & & \\
\hline 25 & $\begin{array}{l}\text { I would like to be a movie } \\
\text { star and I have three rea- } \\
\text { sons about it. }\end{array}$ & & \\
\hline 26 & $\begin{array}{l}\text { There are some benefits } \\
\text { and good advantages for } \\
\text { the people who in the job } \\
\text { that requires a lot of travel } \\
\text { I think. }\end{array}$ & $\begin{array}{l}\text { Red, blue, black, ... we } \\
\text { in daily life. }\end{array}$ & \\
\hline 27 & \multicolumn{13}{c}{$\mathbf{8}$} & \\
\hline Total & & & \\
\hline
\end{tabular}

Table 3: Topic Sentences From Paragraph 2

\begin{tabular}{|c|c|c|c|}
\hline Subjects & Correct & Incorrect & Vague \\
\hline 1 & $\begin{array}{l}\text { There are three courses of } \\
\text { economics in Ritsumeikan } \\
\text { University. }\end{array}$ & & \\
\hline 2 & & & $\begin{array}{l}\text { Almost all of the people } \\
\text { have a television and many } \\
\text { people watch TV show } \\
\text { everyday... (So TV show } \\
\text { is very important role of } \\
\text { people's life because if } \\
\text { affects people's thought and } \\
\text { action. }\end{array}$ \\
\hline 3 & $\begin{array}{l}\text { I think there is there are } \\
\text { similar things between } \\
\text { people whom success. }\end{array}$ & & \\
\hline 4 & $\begin{array}{l}\text { Friends I have had can be } \\
\text { classified into several } \\
\text { groups. }\end{array}$ & & \\
\hline 5 & & & $\begin{array}{l}\text { We have a lot of opportu- } \\
\text { nities of coming across } \\
\text { people. We try to make } \\
\text { friends with them. (There } \\
\text { are several major steps }\end{array}$ \\
\hline
\end{tabular}




\begin{tabular}{|c|c|c|c|}
\hline Subjects & Correct & Incorrect & Vague \\
\hline & & & $\begin{array}{l}\text { involved in getting along } \\
\text { with people we meet for } \\
\text { the first time.) }\end{array}$ \\
\hline \multicolumn{4}{|r|}{ 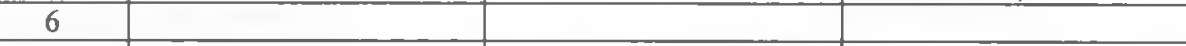 } \\
\hline 7 & $\begin{array}{l}\text { There are some major } \\
\text { steps involved in becom- } \\
\text { ing a successful man. }\end{array}$ & & \\
\hline 8 & $\begin{array}{l}\text { There are three classes of } \\
\text { my courses: }\end{array}$ & & \\
\hline 9 & & & $\begin{array}{l}\text { In general, we can choose } \\
\text { various couces when } \\
\text { entering university ... } \\
\text { (They are many type of } \\
\text { learning in economics.) }\end{array}$ \\
\hline \multicolumn{4}{|r|}{ o } \\
\hline 11 & $\begin{array}{l}\text { There are two types of } \\
\text { success in Professional } \\
\text { Baseball in Japan: }\end{array}$ & & 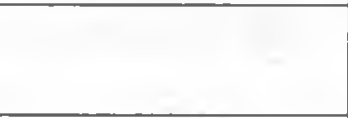 \\
\hline 12 & & & $\begin{array}{l}\text { I've had lots of friends } \\
\text { from my school days and, } \\
\text { of course, they are going } \\
\text { on. (There are four kinds } \\
\text { of friends I can define.) }\end{array}$ \\
\hline 13 & $\begin{array}{l}\text { There are several types of } \\
\text { television shows: }\end{array}$ & & \\
\hline 14 & & & $\begin{array}{l}\text { There are many challeng- } \\
\text { ers in the world. Some } \\
\text { success fortunately, others } \\
\text { fail unfortunately. And } \\
\text { successful people can be } \\
\text { roughly divided three types } \\
\text { by the factors: }\end{array}$ \\
\hline 15 & & & $\begin{array}{l}\text { There are many successful } \\
\text { person in the world. (I } \\
\text { think we can divide them } \\
\text { lucky man and hardwork- } \\
\text { ing person.) }\end{array}$ \\
\hline 16 & $\begin{array}{l}\text { There are two types of } \\
\text { friends. }\end{array}$ & & \\
\hline 17 & & $\begin{array}{l}\text { I want to write Korea of } \\
\text { nation, government and } \\
\text { economy. }\end{array}$ & \\
\hline 18 & & & $\begin{array}{l}\text { We have many successful } \\
\text { people in the world. And } \\
\text { we can classify them into } \\
\text { two types. }\end{array}$ \\
\hline 19 & $\begin{array}{l}\text { There are three types of } \\
\text { automobile driver. }\end{array}$ & & \\
\hline 20 & & & I have majored in Eco- \\
\hline
\end{tabular}




\begin{tabular}{|c|c|c|c|}
\hline Subjects & Correct & Incorrect & Vague \\
\hline & & & $\begin{array}{l}\text { nomic strategy course. } \\
\text { This course is very suitable } \\
\text { for me. There are three } \\
\text { reasons that I chose this } \\
\text { one. }\end{array}$ \\
\hline \multicolumn{4}{|r|}{ (2 } \\
\hline \multicolumn{4}{|l|}{22} \\
\hline 23 & $\begin{array}{l}\text { Though I have many } \\
\text { friends, my friends can be } \\
\text { classified into four groups. }\end{array}$ & & \\
\hline 24 & & $\begin{array}{l}\text { Do you know the } 300 \\
\mathrm{~km} / \mathrm{h} \text { world? }\end{array}$ & \\
\hline 25 & $\begin{array}{l}\text { There are two major ef- } \\
\text { fects that the television } \\
\text { gives. }\end{array}$ & & \\
\hline \multicolumn{4}{|l|}{26} \\
\hline 27 & & & $\begin{array}{l}\text { Today, television is the } \\
\text { part of our life I think. } \\
\text { (And there are many } \\
\text { different types of televi- } \\
\text { sion programs. Then we } \\
\text { can divide television } \\
\text { shows into three big } \\
\text { groups:) }\end{array}$ \\
\hline Total & 11 & 2 & 8 \\
\hline
\end{tabular}

Table 4: Thesis Statements From The Essay

\begin{tabular}{|c|l|l|l|}
\hline Subjects & \multicolumn{1}{|c|}{ Correct } & Incorrect & Vague \\
\hline 1 & $\begin{array}{l}\text { We have to take measures } \\
\text { to cope with the serious } \\
\text { situation as soon as possi- } \\
\text { ble. }\end{array}$ & & \\
\hline 2 & & $\begin{array}{l}\text { So which place do I will } \\
\text { feel comfortable for me? }\end{array}$ & $\begin{array}{l}\text { I have a strong interest in } \\
\text { two things now. }\end{array}$ \\
\hline 3 & & $\begin{array}{l}\text { That which comes exactly } \\
\text { was felt what was packed } \\
\text { by CD-Rom book. }\end{array}$ & \\
\hline 4 & & $\begin{array}{l}\text { These days, we need the } \\
\text { ability of personal com- } \\
\text { puter to follow the society } \\
\text { of information. }\end{array}$ & \\
\hline 5 & & & $\begin{array}{l}\text { Why does spirit be } \\
\text { blamed? Is it true that } \\
\text { phsical technique is more }\end{array}$ \\
\hline 6 & & & \\
\hline
\end{tabular}




\begin{tabular}{|c|c|c|c|}
\hline Subjects & Correct & Incorrect & Vague \\
\hline & & & $\begin{array}{l}\text { important than mental } \\
\text { (=spirit)? Only phisical } \\
\text { and tecnique let the athlete } \\
\text { win the game? }\end{array}$ \\
\hline 7 & & $\begin{array}{l}\text { I respect a certain teacher, } \\
\text { too. }\end{array}$ & \\
\hline 8 & $\begin{array}{l}\text { I am writing about meth- } \\
\text { ods for protecting cold. }\end{array}$ & & \\
\hline 9 & $\begin{array}{l}\text { So, I'd like to talk about } \\
\text { the advantages of putting } \\
\text { plain clothes. }\end{array}$ & & \\
\hline 10 & & $\begin{array}{l}\text { My favorite team is Han- } \\
\text { shin Tigers. }\end{array}$ & \\
\hline 11 & & $\begin{array}{l}\text { I'm very interested in } \\
\text { Alzheimer's disease very } \\
\text { much. I'll give some view. }\end{array}$ & \\
\hline 12 & & & $\begin{array}{l}\text { So there's lots of effort to } \\
\text { get it. }\end{array}$ \\
\hline 13 & & $\begin{array}{l}\text { In this passage, I would } \\
\text { like to pay attention to } \\
\text { trees along street. }\end{array}$ & \\
\hline 14 & $\begin{array}{l}\text { A cellular phone gives us } \\
\text { advantages at the same } \\
\text { time it brings us some big } \\
\text { problems. }\end{array}$ & & \\
\hline 15 & $\begin{array}{l}\text { Therefore, I want to intro- } \\
\text { duce aerobics is best way } \\
\text { to solve these problems, } \\
\text { and some points through } \\
\text { this article. }\end{array}$ & & \\
\hline 16 & & & $\begin{array}{l}\text { I want to talk about ISH- } \\
\text { NIHA which I am excited } \\
\text { recently.... . They are } \\
\text { different from commonly } \\
\text { theatrical team. }\end{array}$ \\
\hline 17 & & $\begin{array}{l}\text { And he is established as } \\
\text { one of the greatest player } \\
\text { of NBA. }\end{array}$ & \\
\hline 18 & & $\begin{array}{l}\text { Autumn has comfortable } \\
\text { climate, delicious foods } \\
\text { and beautiful nature. }\end{array}$ & \\
\hline 19 & & & $\begin{array}{l}\text { Hiphop teaches me the } \\
\text { fact, so I'm going to con- } \\
\text { tinue to think these facts } \\
\text { with hip hop! }\end{array}$ \\
\hline 20 & & $\begin{array}{l}\text { But now, R \& R is popular } \\
\text { music in Japan. I think } \\
\text { why it is. }\end{array}$ & \\
\hline
\end{tabular}




\begin{tabular}{|c|c|c|c|}
\hline Subjects & Correct & Incorrect & Vague \\
\hline 21 & & & $\begin{array}{l}\text { His mental requires to } \\
\text { players, his tactics of } \\
\text { defense and attitude } \\
\text { against soccer association } \\
\text { of Japan must make them } \\
\text { stronger. }\end{array}$ \\
\hline 22 & $\begin{array}{l}\text { But genetic engineering } \\
\text { has both good and bad } \\
\text { points. }\end{array}$ & & \\
\hline 23 & $\begin{array}{l}\text { But Kyudo is, in fact, a } \\
\text { very profound sport and } \\
\text { peculiar to Japan. }\end{array}$ & & \\
\hline 24 & & $\begin{array}{l}\text { I can say that my junior } \\
\text { high school and high } \\
\text { school life is all colored } \\
\text { with color name MET- } \\
\text { ALLCA. }\end{array}$ & \\
\hline 25 & & & $\begin{array}{l}\text { We think it is granted that } \\
\text { there is lot of sounds, but } \\
\text { what is happen if such a } \\
\text { thing should be taken } \\
\text { place. }\end{array}$ \\
\hline 26 & & $\begin{array}{l}\text { My friend, his name is } \\
\text { HY, has bred a gray rabbit. }\end{array}$ & \\
\hline 27 & $\begin{array}{l}\text { Then I'll show you two big } \\
\text { wonderful points of music. }\end{array}$ & & \\
\hline Total & 8 & 12 & 7 \\
\hline
\end{tabular}

On the basis of the results, the number of sentences according to category were then tabulated and are presented in Table 5 below.

Table 5: Percentages of Topic Sentences and Thesis Statements

\begin{tabular}{|l|c|c|c|}
\hline & Correct & Incorrect & Vaguely correct \\
\hline Paragraph 1 & $09 / 23=39 \%$ & $14 / 23=61 \%$ & \\
\hline $\begin{array}{l}\text { Paragraph 1 } \\
\text { (revised) }\end{array}$ & $13 / 22=59 \%$ & $09 / 22=41 \%$ & \\
\hline Paragraph 2 & $11 / 22=50 \%$ & $02 / 22=9 \%$ & $9 / 22=41 \%$ \\
\hline Essay & $08 / 27=30 \%$ & $12 / 27=44 \%$ & $7 / 27=26 \%$ \\
\hline
\end{tabular}

As can be seen from Table 5, students improved in the writing of the two paragraphs but not in the writing of the essay: From paragraph 1, which was a new experience, through its revision to paragraph 2 - interpolated by the essay - the number of correct topic sentences increase. Notice that the number of correct topic sentences go up in the revision from paragraph 1 but drop a little in para- 
graph 2 from the revision. Notice further that the number of correct topic sentences go down in the essay as the interpolation, suggesting that the essay was a new experience again.

The interesting point here is that from paragraph 1 to paragraph 2 the number of incorrect topic sentences decrease but that the number go up again in the essay from the revision, albeit not as high as in paragraph 1 . On the other hand, there are no vaguely correct sentences from paragraph 1 to its revision but they appear significantly in both the essay and paragraph 2, suggesting that their brain functions of memory must have worked for those students, to some extent, on account of their experiences with paragraph 1 and its revision.

\section{Discussion}

Given the aforementioned results, many interesting things can be discussed or speculated, even though the size of the sample is small. However, three points deserve some in-depth discussions here: (1) the differences in the understanding of topic sentence between the two paragraphs on the part of students; (2) the individual variability of students from one paragraph to another paragraph; and (3) the differences of identifying topic sentence and thesis statement among students.

\section{Differences in Understanding}

From the results it can be seen that students have a better understanding of topic sentence after rewriting paragraph 1 for its revision. That is, for some students, the proto-meanings of the notion of topic sentence have begun to sink in after the first paragraph. The change in understanding can be seen in the revisions that were made. Those who got topic sentence rose to $59 \%$ from $39 \%$.

The brain functions require some repetitious stimulations. In order for students to understand the notion, there is a need to have repetition of brain functions which is by no means the same as repeating the same impulses or wording in the brain; rather, it means that the brain is given another opportunity to reorganize what has been written before through the visual stimulation (i.e., one of the five senses) so as to help map the proto-meaning of what the student wanted to say in the first place onto different graphic images.

When students wrote each paragraph or an essay, the brain functions were four dimensional; namely, 3D in the inchoate mass of impulses plus time. This four dimensional reality had to be reduced to each two dimensional word on paper to which was added time as another dimension because words were written in a sequence.

The reduction of four dimensional thinking to three dimensional writing constitutes one of the barriers in language learning, a barrier which students had to overcome. But when students revised paragraph 1 , differing brain functions 
were employed. They had visual aid coupled with the brain functions of memory. The paragraph was written on paper already by students and they needed only to shuffle words and sentences around by using at the same time the incoming stimuli from the visual aid and relying on their brain functions of memory. Thus, this repetition did help students think of the notion of topic sentence again with one less barrier, as may be evidenced by the results.

Because some students did better in the revision of their paragraphs, with the visual aid and the help of the brain functions of memory, the exercise should give credence to the idea that students write out a paragraph in Japanese first in order to stimulate their brain functions for the identification of the topic sentence in the paragraph as a practice. In so doing, students may then be able to realize what the proto-meaning of a topic sentence is, thereby facilitating the removal of one barrier of language learning in the next attempt to write another paragraph insofar as the formulation of topic sentence in English is concerned.

The repetitive brain functions of memory in writing the second paragraph helped students as well, albeit not as much as in the revision. Had they practiced the writing of paragraphs in Japanese first, they would have made an even more significant improvement in writing the second paragraph.

Recall that students had previously written paragraph 1 , along with the revision, and had also written the essay before the second paragraph; they had had practice in writing topic sentences. Thus, the number of correct topic sentences in paragraph 2 was at $50 \%$, even though the figure was not as high as in the revision (59\%). Even so, it can be said that by the time of writing paragraph 2 , it seems that the barrier mentioned above for some students started to break down. They were beginning to understand the notion of topic sentence as they had had practice to stimulate some brain functions of memory for writing such sentences in paragraphs.

\section{Individual Variability of Students}

From Tables 1, 2, 3, and 4 it can be seen that some students, though not all of them did improve individually:

(1) There are changes in individual students for paragraph 1 and the revision; namely, student 12, student 14, student 23, and student 15 .

Student 12 first had an incorrect topic sentence, I now belong to the Finance Institute, Economics. Then, in the revision, the student wrote I chose the Finance Institute in the faculty of Economics for several reasons. The topic sentence now has the topic and the controlling idea (the focus of the paragraph). However, this student slipped back to "vaguely correct category" in the essay and paragraph 2 .

Student 14 also had a general sentence, $I$ wouldn't like to be a movie star, which was incorrect. In the revision, the student wrote, I would not like to be a movie star for some reasons. Grammatically, the sentence may not be correct. 
However, the student tried to get in the controlling idea or focus. Unlike student 12 , student 14 got the notion right in the essay, due probably to practice in the revision, but slipped back to "vaguely correct category" in paragraph 2.

Student 23 improved too. He wrote, There are lucky color and unlucky color for me. The sentence does not reflect what he wrote about afterward. The student revised the paragraph and wrote, My feeling is often affected by color which is correct. His sentences in the essay and paragraph 2 remained correct, suggesting that he had benefited a great deal from his brain functions of memory through practice in the revision.

There was also a student who improved, but the sentence was not the first sentence that appeared in the paragraph. Student 15 first wrote, Movie star act many characters. The student then revised the paragraph to, I long for a movie star from childhood, but when it comes to the crunch, I wouldn't like to be a movie star. It is still incorrect, but the student tried to reflect his attitude about the topic which was some improvement, thereby enabling student 15 to write a correct thesis statement in the essay, albeit slipping back to "vaguely correct category" in paragraph 2 .

(2) When comparing paragraphs 1 and 2 there are also changes. Some student improved. Student 4 and 11 improved with topic sentence.

For student 4, in the original paragraph 1, he wrote, Even if it listens with "What kind of occupation do you want to get in the future? Or, what do I want to do? "I can answer that soon. He did not change this sentence in the revision, even though this topic sentence was not clear. So, it was still incorrect. He went on to write in the essay, That which comes exactly was felt what was packed by $C D$-Rom book. as the first sentence, meant to be the thesis statement. And yet he still did not get it right. However, after three practices, with paragraph 1 , its revision, and the essay, for paragraph 2 , the topic sentence is clearly correct, Friends I have had can be classified into several groups.

By contrast, student 11 in paragraph 1 was incorrect when he wrote, To go abroad to work is many people are required in the future. He changed it in the revision as I want to go where people speak English by not a travel but work which is still incorrect. Even in the essay, he wrote, I'm very interested in Alzheimer's disease very much. I'll give some view, which is also incorrect. Not until he had had three practices, like student 4 , did student 11 in paragraph 2 write, There are two types of success in Professional Baseball in Japan, which is a correct topic sentence.

(3) There were also students whose topic sentences improved but each of the sentences was not written as the first sentence of the paragraph. The sentences were thus judged vaguely correct as mentioned above. That is, students 2,5 , and 20 had a incorrect topic sentence in paragraph 1 and then wrote a topic sentence which was not the first sentence in paragraph 2 .

Student 2 first wrote the following in paragraph 1: I major in Economic, which he repeated in the revision. Then, in the essay, he wrote, I have a strong 
interest in two things now, which is put under "vaguely correct category." Even in paragraph 2, after three practices, student 2 still wrote, So TV show is very important role of people's life because it affects people's thought and action which may look like the topic sentence for the paragraph. That is, it can be seen that the student wanted to discuss the effects of TV on people's thoughts and actions. But this point was not mentioned at the start of the paragraph; in other words, the seemingly correct sentence was no the first sentence in the paragraph.

In contrast, student 5 had an incorrect topic sentence for paragraph 1, Color actually affects. It is a very general sentence and does not give much focus for the paragraph but was repeated in the revision. In the essay, student 5 wrote, These days we need the ability of personal computer to follow the society of information, which is still incorrect. Then, in paragraph 2, even after three practices, the student did not have a topic sentence as the first sentence. He wrote, We have a lot of opportunities of coming across people. We try to make friends with them. There are several major steps involved in getting along with people we meet for the first time. Student 5 gave a clear sentence for paragraph 2 as the likely topic sentence. But the student went on to write about steps to make friends, which were probably what he had in mind as the proto-meanings. Only having the three sentences together would the reader be able to realize such hidden proto-meanings in the linguistic meaning of the first sentence.

Student 20 was similar to student 5 . He wrote the following in paragraph 1: Movie gives us an impossible dream. For its revision, he wrote, I think a movie star is a brilliant job, which is still incorrect. Then, in the essay, he wrote, But now, $R \& R$ 's popular music in Japan. I think why it is, which is also incorrect. However, in paragraph 2, he wrote I have majored in Economic strategy course. This course is very suitable for me. There are three reasons that I chose this one. Here, student 20 wrote the thesis statement in tow sentences. The subject matter is in the first sentence, but then the aspect of the subject for focus in not mentioned until later when he stated that the would give 3 reasons.

(4) For students $9,12,14,18$, and 27, they wrote correct sentences in the rewriting of paragraph 1 , but either wrote a seeming topic sentence with a wrong follow-up or did not write the topic sentence as the first sentence for paragraph 2.

Student 9 wrote, There are many kinds of job that requires lots of travel. in paragraph 1, which is correct, and maintained it in the revision. He also got the thesis statement right in the essay, which was, So, I'd like to talk about the advantages of putting plain clothes. In paragraph 2, however, he wrote, In general, we can choose various courses when entering university... There are many type of learning in economics. This is put under "vaguely correct category". The paragraph was not about types of learning; rather, the student discussed the various courses in 
economics. Moreover, the third sentence was written well like a thesis statement. Therefore, what he wrote is a hybrid of two things (or concepts) mistakenly put together; namely, (1) the production of a seeming topic sentence to be followed by something having nothing to do with the topic sentence and (2) the production of a seeming thesis statement without any elaboration of the thesis.

Student 12 wrote, I, now, belong to the Finance Institute, Economics, in paragraph 1. It is incorrect, but he revised it correctly as follows: I chose the Financial Institute in the Faculty of Economics for several reasons. However, he slipped back to "vaguely correct category" in the essay: So, there's lots of effort to get it. In paragraph 2, he maintained this vague category as he wrote, l've had lots of friends from my school days and, of course, they are going. There are four kinds of friends I can define. The first sentence in paragraph 2 is not clear, but then the second sentence could have served as the topic sentence, which is quite clear, had it been the first sentence.

Student 14 wrote the following for paragraph 1: I wouldn't like to be a movie star which is incorrect. But he revised it correctly as follows: I would not like to be a movie star for some reasons. His writing of the thesis statement in the essay remained correct: A cellular phone gives us advantages at the same time it brings us some big problems. For paragraph 2, however, he slipped back to "vaguely correct category" by writing, There are many challengers in the world. Some success fortunately, others fail unfortunately. And successful people can be roughly divided three types by the factors.

The first sentence of paragraph 2 is very general, but the third sentence which cannot serve as the topic sentence gives a clear focus for the paragraph. The student then listed afterward three factors to be discussed in the same paragraph.

Student 18 had an incorrect topic sentence in paragraph 1: Many kinds of color affect me two influences. But she revised it correctly as: Many kinds of color affect us in two ways. When it came to the writing of the essay, which was a new experience again, she slipped back to "incorrect category" as follows: Autumn has comfortable climate, delicious foods and beautiful nature. She improved in paragraph 2 by writing, We have many successful people in the world. And we can classify them into two types.

This paragraph nevertheless did not have her topic sentence as the first sentence. The topic sentence would have become very clear had the first two sentences been combined as the first sentence of the paragraph.

For student 27 in paragraph 1 she wrote, There are some benefits and good advantages for the people who in the job that requires a lot of travel I think. Since this was correct, she retained it in the revision. She also got the thesis statement in the essay right: Then I'll show you two big wonderful points of music. But she slipped to "vaguely correct category" for paragraph 2 when she 
wrote, Today, television is the part of our life I think. And there are many different types of television programs. Then, we can divide television shows into three big groups. The third sentence is a very clear topic sentence, but it is not the first sentence.

\section{Differences Between Topic Sentence and Thesis Statement}

The topic sentence in a paragraph and the thesis statement in an essay do not differ from each other very much. The thesis statement is the topic sentence for the essay. However, there are more difficulties for students to get the thesis statement correct, as may be evidenced by the examples given above. Two factors may be considered here: (1) new versus old experiences when students encountered each writing; (2) the sheer differences in length between a paragraph and an essay. These two factors are interrelated.

When students were assigned paragraph 1 , it was a new experience to them. So, most of them did not get the topic sentence right, which is understandable. For the assignment of revising paragraph 1, the experience was no longer new. However, when they were assigned the essay, the experience was new again because of the differences in length which also explains why students also did better in paragraph 2 than in the essay, albeit not as well as in paragraph 1 . Therefore, it is of significance that the differences between topic sentence and thesis statement are further looked into in the four assignments. Bear in mind that there are still some students who got the thesis statement wrong for the essay, even though they had the topic sentence correct in paragraph 1: students 3 , and 13. There are also students who got the thesis statement right but did not get the topic sentence right in paragraph 1: students $14,15,23$.

And there are two other students who understood the idea of topic sentence in paragraph 1 , but did not have a clear thesis statement in their essays: student 21 and 25.

Student 3 wrote, If I have a time to go for a trip this weekend, I'd like to go to Kyoto, for paragraph 1. This was retained in the revision. In the essay, however, he wrote, So which place do I will feel comfortable for me. Student 3 proceeded to explain in the essay the advantages and disadvantages of living in the various countries he had visited. The thesis statement was incorrect because it needed to be revised to reflect the focus of his essay. But, interestingly enough, he got the topic sentence right in paragraph 2 as follows: I think there is there are similar things between people whom success.

Student 13 wrote the following as the topic sentence in paragraph 1 correctly: The reasons that I selected human economy course is to think how will 
be people and environment of the world in the future. He retained this in the revision. In the essay, however, he incorrectly wrote the following as the thesis statement: In this passage, I would like to pay attention to trees along street. But his topic sentence in paragraph 2 was, again, correct: There are several types of television shows.

In the case of student 13 , there were definite barriers in his thinking patterns for the essay: He was not able to adequately map the proto-meanings onto the graphic images in English to carve out (i.e., unlock) the linguistic meanings in English. He was attempting to explain the layout of streets in Japan and the damage on trees, rather than the trees themselves as might be surmised (i.e., reconstructed) from the linguistic meaning of the sentence he wrote.

Student 14 is one who wrote an incorrect topic sentence for paragraph 1 . He wrote, I wouldn't like to be a movie star. This sentence was simply a statement. So, he revised it correctly as $I$ would not like to be a movie star for some reasons. But he wrote a correct thesis statement for the essay, which was, $A$ cellular phone gives us advantages at the same time it brings us some big problems. It is a very well formulated thesis statement giving the focus of the essay. Be that as it may, he slipped back to "vaguely correct category" in paragraph 2 . There are many challengers in the world. Some success fortunately, others fall unfortunately. And successful people can be roughly divided three types by the factors.

Student 15 also wrote a correct thesis statement. In paragraph 1 she wrote, Movie star act many characters. This was a very general statement. It was revised and the revision was still incorrect, I long for a movie star from childhood, but when it comes to the crunch, I wouldn't like to be a movie star. In the essay, however, she wrote, Therefore, I want to introduce aerobics is best way to solve these problems, and some points through this article. It is still a little general, but student 15 did introduce some ways to solve problems of obesity, health problems through exercise. So, it was considered correct. But, in paragraph 2, she slipped back to "vaguely correct category" as follows: There are many successful person in the world. (I think we can divide them lucky man and hardworking person.)

Student 23 in paragraph 1 wrote incorrectly, There are lucky color and unlucky color for me. It was revised correctly as My feeling is often affected by color. Then, in the essay, he also wrote correctly, But Kyudo is, in fact, a very profound sport and peculiar to Japan. He remained correct in the writing of paragraph 2, Though I have many friends, my friends can be classified into four groups.

Student 21 in paragraph 1 wrote correctly, If I could live in any period of time, I would like to live in the end of Edo period. This correct topic sentence was maintained in the revision. Then, in the essay, he wrote, His mental requires to players, his tactics of defense and attitude against soccer association of Japan must make them stronger. It was difficult form the essay to understand 
what the student was trying to discuss. Student 21, however, did not submit his assignment of paragraph 2; presumably he gave up on it.

Student 25 wrote correctly the following for paragraph1: I would like to be a movie star and I have three reasons about it. This correct topics sentence was maintained in the revision. In the essay he wrote, We think it is granted that there is a lot of sounds, but what is happen if such a thing should be taken place. The student attempts to describe in the essay about what might happen if there were no music. Thus, it is vague as to what the student might have really meant. However, he got paragraph 2 right again, There are two major effects that the television gives.

When examining all four writing examples, paragraph 1, revision, paragraph 2 and the essay, there are a few students who consistently wrote correct topic sentences and thesis statements. Those students are students 1 , and 8 . These two students are the only ones out of 27 , who correctly wrote a topic sentence and thesis statement. Once paragraph 1 was revised there were two more students, namely, students 9 and 23 , who also correctly wrote a topic sentence for paragraph 2 and then a thesis statement for the essay.

\section{Residual Remarks}

Recall that there were students whose topic sentences or thesis statements were categorized as vaguely correct. And as was discussed briefly, the author was unable to reconstruct the proto-meanings from the linguistic meanings. It was a challenge to match the definition of topic sentence by Blanchard and Root to the writings from the students' linguistic meaning of each such sentence under the vaguely correct category.

For instance student 2 in the essay had $I$ have a strong interest in two things now. The linguistic meaning of this sentence is clear. But in order for this statement to be a thesis statement, something else must be added which is missing because it is left behind in the student's head: the instructor cannot have access to it unless more is written down by the student to clarify what the protomeaning is. Here this sentence is regarded as vaguely correct.

For student 6 in the essay, it can be seen that the linguistic meanings may be reconstructed, but the proto-meaning is not clear. He states, Why does spirit be blamed? Is it true that physical and technique is more important than mental (=spirit)? Only physical and technique let the athlete win the game? Only after reading the essay can the reader understand some of what student 6 was trying to say. Nevertheless, there are still meaning which are not clear, that is, cannot be reconstructed. In particular, the vocabulary items of spirit, physical and technique and mental are all rather vague from reading the essay. 


\section{Conclusion}

Given the results of the two paragraphs, one revision, and the essay and the discussion thereof, several conclusions can be drawn from them. First, it is clear that teaching a foreign language for either oral production or writing to students of another language must find accessible pathways to the students' protomeanings. Such pathways are multifactorial. Clearly the students need more vocabulary which must be stored in their brains as graphic or stored images.

Second, how to make the student understand what the instructor or textbook means, such as topic sentence or thesis statement, requires repetition which may be the same materials rearranged or through another exercise. This repetition can be facilitated by reducing the four dimensional inchoate mass of impulses into three dimensional writing for visual manipulation. For example, writing paragraph 1 and revising it.

Third, there is a big gap between writing a paragraph in which the topic sentences can be identified to writing an essay in which the thesis statement must be identified. The data who that $39 \%$ of the students correctly wrote a topic sentence in paragraph 1 , and $50 \%$ of them did so in paragraph 2 , whereas only $30 \%$ of the students correctly wrote a thesis statement. And out of these students only 2 students were consistently able to write correctly a topic sentence for each paragraph and a thesis statement for the essay.

The thought process in thinking patterns for students to learn to write is complex indeed, as they have not acquired sufficient brain functions of memory in English for reading, speaking or listening, let alone, writing English. In Japan, primary focus for English in high schools is placed on grammatical constructions, vocabulary, reading comprehension, listening, and some spoken and written English. The latter two are not as essential for they are not pertinent to the passing of university entrance examinations. Thus, when studying writing, the approach taken by the teach should be examined. Are students to begin to write by osmosis? Students need to write as much as possible. There are times when students must write as much as possible, no matter what the grammatical expression. They also do not have the concept of inductive reasoning in their minds to write a composition, not to mention the difficulty of expressing words into written English, a non-native language, from their inchoate mass of impulses that constitutes their native thoughts. Put differently, they also have to increase their experiences with English in order to enhance their brain functions of memory to incorporate proto-meanings and linguistic meanings of English into their inchoate mass of impulses.

The teacher must, therefore, provide the steps in order for students to arrange the proto-meanings into linguistic meanings in English. Students have already had some form of understanding of writing in their minds for Japanese. However, that understanding of writing is segmented in certain ways. The teacher must provide ways to form linguistic meanings of English in students by 
using many examples of writing, such as trying to guide them to reconstruct some of the proto-meanings which students already have on the basis of their experiences with writing in Japanese and to construct some proto-meanings which students have not experienced with writing in English.

The whole purpose of teaching English as a foreign language is to do what has been mentioned above. However, the focus here is specifically about writing. Students must read and hear what the teacher is explaining. But they also must practice what the teacher is teaching as well. Students cannot reconstruct some of the meanings that are taught. Therefore, students must be provided with information, i.e., concrete steps, to construct and reconstruct meanings.

Many a time the teacher already has the meanings in his/her mind and expects the student to be able to reconstruct those meanings just by lecturing. However, students of a foreign language have extra barriers to face. They must reconstruct meanings in a foreign language as well as reconstruct meanings from the different cultural experience. Therefore, the barriers are greater. Students must be given gradual guidance to step into writing, no matter what level they are in.

Finally, the steps to be taken as remedy in writing may be suggested as follows: (1) Enhance each student's brain functions of memory by (a) a graded increase in vocabulary of the selected area (or domain) of interest, (b) a progressive approach to writing from familiar subjects (e.g., day-to-day encounters) to less familiar subjects (e.g., politics, human rights, etc.), and (c) a multichanneled involvement of experience in English for activating the student's five senses; (2) make full use of repetition in writing, such as revision of the same assignment; and (3) practice in writing the new concepts to be introduced (e.g., topic sentence and thesis statement ) in the student's own native language first, and then gradually guide students in class to change (or switch) the new concepts in their minds into similar, if not corresponding, concepts in the target language, i.e., English in the present context.

There are, of course, limitations in those suggestions one of which is the time factor, because those suggestions will undoubtedly demand more time from the instructor: for instance, the instructor must also be able to read what is written by the student in his/her own language, thereby giving an extra burden to the instructor. Also needed is the cooperation from the administration of an institution to incorporate the time for writing in the curriculum, which is quite another matter. Nevertheless the efforts may be worthwhile if the job of teaching is considered a mission.

\section{REFERENCES}

Blanchard, K.; Root, C. (1997): Ready to write more. New York: Longman.

Peng, F.C.C. (2000): Review article of Thibault's "Re-reading Saussure: The dynamics of signs in social life". Lingua Posnaniensis 42, 59-81.

Thibault, P.J. (1997): Re-reading Saussure: The dynamics of signs in social life. London and New York: Routledge. 